\title{
Pengaruh Earning Per Share Terhadap Return On Asset Serta Dampaknya Terhadap Harga Saham PT. EInusa Tbk
}

\author{
Sydney Joana ${ }^{1}$, Endang Pitaloka ${ }^{2}$ \\ ${ }^{1}$ Program Studi Manajemen, Universitas Pembangunan Jaya, sydjoandrea@gmail.com \\ ${ }^{2}$ Program Studi Manajemen, Universitas Pembangunan Jaya, oka@upj.ac.id
}

\begin{abstract}
The aim of This research is to examines the indirect effect of Earning per Share (EPS), on Stock Price (SP) through Return on Asset (ROA) at crude petroleum and natural gas production company PT. Elnusa Tbk. This research used secondary: monthly financial report data as much as 36 samples during January 2012 - December 2014 the data anlayzed using path analysis model. The results showed that Earning per Share has significant effect on Return on Asset, and Return on Asset has significant effect on Stock Price.The This proofed that Return on Asset as an intervening variable between Earning per Share and Stock Price. In PT Elnusa, Tbk. Earning per Share (EPS) has significant effect on Stock Price (SP) through Return on Asset (ROA).
\end{abstract}

Keywords: Earning per Share (EPS), Return on Asset (ROA), Stock Price (SP)

\begin{abstract}
Abstrak : Penelitian ini bertujuan untuk mengkaji pengaruh tidak langsung dari Earning per Share (EPS) terhadap Harga Saham (SP) melalui Return on Asset (ROA) pada perusahaan minyak mentah dan gas alam PT Elnusa Tbk. Penelitian ini menggunakan data sekunder berupa laporan keuangan bulanan periode Januari 2012 hingga Desember 2014. Total data yang digunakan sebanyak 36 sampel. Teknik analisa data yang digunakan adalah analisa jalur (path analysis). Hasil penelitian menunjukan bahwa variabel Earning per Share berpengaruh secara signifikan terhadap variabel Return on Asset dan variabel Return on Asset berpengaruh secara signifikan terhadap Harga Saham. Hasil tersebut mebuktikan bahwa variabel Return on Asset adalah variabel intervening dari variabel Earning per Share dengan variabel Harga Saham. Dapat disimpulkan bahwa pada PT. Elnusa Tbk, Earning per Share (EPS) berpengaruh terhadap Harga Saham (SP) melalui Return on Asset (ROA).
\end{abstract}

Kata kunci : Earning Per Share (EPS), Return on Asset (ROA), Harga Saham (SP)

\section{LATAR BELAKANG}

Bisnis miyak dan gas bumi saat ini merupakan salah satu jenis sumber daya alam yang sangat dibutuhkan oleh banyak negara, tak terkecuali Indonesia. Terlepas dari fungsi utamanya sebagai sumber energi dalam bentuk bahan bakar, tetapi juga sebagai sumber penghasilan negara dalam bentuk ekspor. Di masa yang akan datang, kebutuhan akan sumber daya alam ini akan meningkat karena tingginya kebutuhan akan minyak dan gas bumi menjadikannya komoditas strategis yang banyak menyita perhatian banyak pihak.

Sumber daya migas termasuk sumber daya alam yang tidak bisa dipengaruhi maka ada banyak faktor yang menyebabkan harga sumber daya migas berfluktuasi. Faktor-faktor tersebut diantaranya jumlah cadangan migas yang tersedia, kondisi perekonomian negara, dan katel OPEC Setiadi (2015). Hal ini juga terjadi di Indonesia. Salah satu dampak dari fluktuasi harga tersebut adalah kinerja investasi perusahaan migas.

Bagi perusahaan migas yang terdaftar dalam Bursa Efek Indonesia kinerja investasi sangat penting untuk memperoleh kepercayaan investor. Demikian juga dengan investor, dalam mengambil keputusan untuk berinvestasi 
umumnya investor akan melakukan analisa kinerja perusahaan.

Untuk mengukur kinerja suatu perusahaan, biasanya digunakan analisis rasio-rasio keuangan untuk mengetahui beberapa aspek yang berpengaruh terhadap posisi keuangan serta perkembangan perusahaan tersebut. Rasio keuangan adalah alat yang berharga dalam memahami dan memantau posisi keuangan perusahaan dan kinerja. Indikator utama untuk meningkatkan kinerja perusahaan adalah memaksimalkan kemakmuran para pemegang saham melalui nilai perusahaan. Semakin tinggi nilai perusahaan menggambarkan bahwa semakin tinggi pula kesejahteraan para pemiliknya.

Selain rasio keuangan hal lain yang menjadi pertimbangan investor adalah harga saham. Harga saham adalah faktor yang membuat para investor menginvestasikan dananya di pasar modal dikarenakan dapat mencerminkan tingkat pengembalian modal dimana investor membeli saham adalah untuk mendapatkan dividen serta menjual saham tersebut pada harga yang lebih tinggi (capital gain). Para emiten yang dapat menghasilkan laba yang semakin tinggi nilainya maka akan meningkatkan tingkat pengembalian yang akan diperoleh investor yang tercermin dari harga saham di perusahaan tersebut.

Terdapat 4 perusahaan minyak dan gas bumi yang terdaftar di Bursa Efek Indonesia. Salah satu perusahaan energi minyak bumi dan atau gas bumi yang berkinerja sangat baik adalah PT. Elnusa Tbk. Hal ini dapat dilihat dari besarnya nilai rasio Return on Asset (ROA) dibandingkan dengan perusahaan lainnya. Rasio ini menunjukkan berapa besar laba bersih diperoleh perusahaan bila diukur dari nilai asetnya (Riyanto, 2010). Tabel 1 menyajikan rasio keuangan perusahaan Migas yang terdaftar di BEI. Dari tabel tersebut diketahui bahwa harga saham PT. Elnusa (ELSA) mengalami fluktuasi sepanjang 2012-2014. Trend harga saham ELSA tidak konsisten dengn ROA yang terus naik sepanjang 2012-2014. Padahal nilai ROA yang semakin besar menunjukan profitabilitas perusahaan yang meningkat. Umumnya profitabilitas meningkat seiring dengan harga saham yang juga meningkat. Demikin juga dengan rasio EPS. Nilai rasio EPS yang tinggi akan meningkatkan minat investor untuk membeli saham tersebut karena tingkat pengembalian yang besar. Fenomena berdasarkan data periode 20122014 menunjukan bahawa trend kenaikan EPS juga tidak konsisten dengan trend harga saham yang berfluktuasi. Hal ini menjadikan peneliti tertarik meneliti faktor apa yang mempengaruhi harga saham PT. Elnusa Tbk. Oleh karena itu tujuan penelitian ini adalah: untuk mengetahui pengaruh Earning per Share (EPS) terhadap Harga Saham melalui Return on Asset (ROA).

Tabel 1. Perkembangan EPS, ROA dan Harga Saham Perusahaan Minyak dan Gas Bumi Tahun 2012-2014

\begin{tabular}{ccccc}
\hline $\begin{array}{c}\text { Kode } \\
\text { Perusa } \\
\text { haan }\end{array}$ & Tahun & $\begin{array}{c}\text { EPS } \\
\text { (Rp) }\end{array}$ & $\begin{array}{c}\text { ROA } \\
(\%)\end{array}$ & $\begin{array}{c}\text { Harga } \\
\text { Saham } \\
\text { (Rp) }\end{array}$ \\
\hline \multirow{3}{*}{ MEDC } & 2014 & 46 & 0.60 & 1,630 \\
\cline { 2 - 5 } & 2013 & 139 & 0.70 & 2,100 \\
\hline \multirow{3}{*}{ ENRG } & 2012 & -10 & -0.10 & 3,800 \\
\cline { 2 - 5 } & 2014 & 15 & 2.60 & 82 \\
\hline \multirow{3}{*}{ ELSA } & 2012 & 3 & 0.60 & 100 \\
\cline { 2 - 5 } & 2014 & 53 & 9.30 & 330 \\
\hline & 2012 & 15 & 2.60 & 245 \\
\hline \multirow{2}{*}{ BIPI } & 2014 & 9 & 2.0 & 196 \\
\cline { 2 - 5 } & 2013 & 10 & 3.7 & 111 \\
\hline & 2012 & 1 & 0.6 & 121 \\
\hline
\end{tabular}

Sumber: www.idx.co.id

\section{KAJIAN PUSTAKA}

\section{Earning Per Share (EPS)}

Earning per Share (EPS) adalah perbandingan antara pendapatan yang dihasilkan (laba bersih) dan jumlah saham yang beredar (Gitman, 2012). Earning per Share dirumuskan dengan perbandingan 
antara laba siap bagi dengan total lembar saham sebagaimana tercantum dalam laporan keuangan per Desember (Harahap, 2010).

Menurut Fahmi (2012), Earning per Share menggambarkan profitabilitas perusahaan yang tergambar pada setiap lembar saham. Jika perusahaan menambah modal saham dengan mengeluarkan lembar saham baru sementara laba tidak berubah, maka EPS akan semakin kecil. Sebaliknya, jika perusahaan menambah modal saham dengan mengeluarkan lembar saham baru sementara laba berubah, maka EPS akan semakin besar.

Rumus EPS adalah sebagai berikut:

$E P S=\frac{\text { Net Income }- \text { Prefferd Devidens }}{\text { Average Number of Commen Share Outstanding }}$

\section{Return On Asset (ROA)}

Return on Aset merupakan perbandingan antara laba bersih dengan total aset. Teori Return on Aset yang dikemukakan oleh Harahap (2010) bahwa semakin besar ROA semakin bagus karena perusahaan dianggap mampu dalam menggunakan aset yang dimilikinya secara efektif untuk menghasilkan laba. Rasio digunakan untuk mengukur kemampuan perusahaan dalam menghasilkan laba yang berasal dari aktivitas investasi. Tinggi rendahnya Return on Aset tergantung pada pengelolaan aset perusahaan oleh manajemen yang menggambarkan efisiensi dari operasional perusahaan (Fahmi, 2012). ROA yang semakin tinggi adalah ROA yang semakin efisien operasional perusahaannya. Sebaliknya, ROA yang rendah dapat disebabkan oleh banyaknya aset perusahaan yang menganggur, investasi dalam persediaan yang terlalu banyak dan lain-lain (Gitman, 2012). Rumus ROA sebagi berikut

$R O A=\frac{\text { Net Income }}{\text { Total Asset }}$

\section{Harga Saham (SP)}

Saham merupakan salah satu dari bermacam-macam surat berharga (efek) yang umum diperjualbelikan melalui bursa efek (Sihombing, 2008). Pada sisi yang lain, saham merupakan instrumen investasi yang banyak dipilih para investor karena saham mampu memberikan tingkat keuntungan yang menarik. Sebagai sebuah surat berharga, saham dapat diperjualbelikan setiap hari melalui bursa efek melalui pasar reguler maupun pasar negoisasi. Pada transaksi di pasar reguler, transaksi dilakukan berdasarkan harga saham yang saat itu terjadi di pasar. Sedangkan transaksi di pasar negosiasi terjadi apabila pembeli dan penjual sepakat untuk melakukan transaksi sebuah saham pada sebuh harga tertentu, yang belum tentu merupakan harga pasar (Baye \& Prince, 2016).

\section{Penelitian Terdahulu}

Penelitian yang mengkaji pengaruh EPS, ROA terhadap Harga saham telah dilakukan oleh beberapa peneliti sebelumnya. Beberapa penelitian tersebut tersaji dalam Tabel 2.

\section{Kerangka Berpikir}

Berdasarkan kajian penelitian sebelumnya pada Tabel 2, maka kerangka pemikiran dalam penelitian ini adalah sebagai berikut:

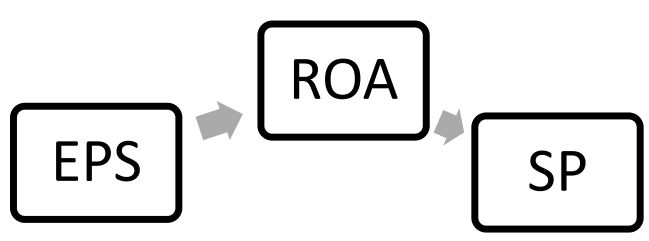

Gambar 1. Kerangka pemikiran.

\section{Hipotesis Penelitian}

Hipotesis penelitian ini adalah:

$H$ : Earning per Share (EPS) berpengaruh terhadap Harga Saham (SP) Melalui Return on Asset (ROA)

\section{METODE PENELITIAN}

Penelitian ini menggunakan metode penelitian kuantitatif. Sumber data dalam penelitian ini adalah data sekunder berupa laporan keuangan bulanan PT. Elnusa Tbk. periode Januari 2012 hungga Desember 2014. 
Tabel 2. Penelitian Terdahulu

\begin{tabular}{|c|c|c|}
\hline No & Peneliti & Hasil Penelitian \\
\hline 1 & $\begin{array}{l}\text { Deitiana } \\
(2012)\end{array}$ & $\begin{array}{l}\text { Profitabilitas ROA memiliki pengaruh positif yang signifikan terhadap harga } \\
\text { saham. Deviden memiliki pengaruh positif yang signifikan terhadap nilai harga } \\
\text { saham. Likuiditas memiliki pengaruh positif yang signifikan terhadap harga } \\
\text { saham. Pertumbuhan Penjualan memiliki pengaruh negatif yang signifikan } \\
\text { terhadap harga saham. Profitabilitas, likuiditas, pertumbuhan penjualan dan } \\
\text { deviden secara bersama-sama atau simultan memiliki pengaruh yang signifikan } \\
\text { terhadap harga saham. }\end{array}$ \\
\hline 2 & $\begin{array}{l}\text { Hanum } \\
(2015)\end{array}$ & $\begin{array}{l}\text { Secara simultan variabel ROA, ROE dan EPS mempengaruhi Harga Saham } \\
\text { secara signifikan. Secara parsial hanya variabel ROA yang tidak mempengaruhi } \\
\text { Harga Saham. Variabel EPS juga memiliki pengaruh terhadap ROA dan Harga } \\
\text { Saham secara parsial. }\end{array}$ \\
\hline 3 & $\begin{array}{l}\text { Astria } \\
(2015)\end{array}$ & $\begin{array}{l}\text { Earning Per Share dan Current Ratio berpengaruh secara simultan terhadap } \\
\text { harga saham sebesar } 72.2 \% \text {. Sedangkan sisanya sebesar } 27.8 \%(100 \%-72.2 \\
\%) \text { harga saham dipengaruhi oleh factor lain yang tidak tercakup dalam } \\
\text { penelitian ini. Adapun secara parsial, Earning Per Share berpengaruh terhadap } \\
\text { harga saham sebesar } 71.4 \% \text { sedangkan Current Ratio berpengaruh terhadap } \\
\text { harga saham sebesar } 0.4 \% \text {. }\end{array}$ \\
\hline 4 & $\begin{array}{l}\text { Abdulah, } \\
\text { Soedjatmi } \\
\text { ko, } \\
\text { Hartati } \\
(2016)\end{array}$ & $\begin{array}{l}\text { Secara simultan DER, EPS, Per dan ROA berpengaruh secara signifikan } \\
\text { terhadap Harga Saham. Secara parsial hanya variabel DER yang berpengaruh } \\
\text { terhadap Harga Saham. Variabel EPS juga tidak berpengaruh secara signifikan } \\
\text { terhadap ROA. Ketidak berpengaruhan tersebut terjadi karena pada petrusahaan } \\
\text { tambang ada faktor lain di luar perusahaan seperti kondisi makroekonomi yang } \\
\text { berpengaruh terhadap harga saham. }\end{array}$ \\
\hline
\end{tabular}

\section{METODE PENELITIAN}

Penelitian ini menggunakan metode penelitian kuantitatif. Sumber data dalam penelitian ini adalah data sekunder berupa laporan keuangan bulanan PT. Elnusa Tbk. periode Januari 2012 hungga Desember 2014. Dengan periode tersebut maka terdapat 36 data sebagai sampel dalam penelitian ini. Data tersebut kemudian diolah menggunakan teknik analisa jalur (path analysis).

Teknik ini digunakan untuk menguji besarnya sumbangan (kontribusi) yang ditunjukkan oleh koefisien jalur pada setiap model jalur dari hubungan kausal antar variabel (Ghozali, 2013).

Model jalur ialah suatu diagram yang menghubungkan antara variabel bebas, perantara dan teikat (Maisaroh \& Mawardi, 2015). Dalam penelitian ini variabel EPS adalah variabel bebas, variabel ROA adalah variabel perantara (intervening) dan varibal SP adalah variabel terikat.
Untuk menguji pengaruh antar variabel sesuai dengan hipotesis penelitian maka digunakan uji-t berdasarkan nilai tingkat keyakinan 95\% $(\alpha=5 \%=0.05)$. Dimana pengaruh antar variabel dinilai signifikan jika probabilitas $(\mathrm{P}) \leq 0.05$.

\section{HASIL DAN PEMBAHASAN}

Dari teknik analisa data path analysis diperoleh hasil sebagaimana ditunjukkan dalam Tabel 3.

Tabel 3. Hasil Estimasi

\begin{tabular}{cccc}
\hline $\begin{array}{c}\text { Pengaruh } \\
\text { Variabel }\end{array}$ & $\begin{array}{c}\text { Esti } \\
\text { mate }\end{array}$ & P & Ket. \\
\hline ROA - EPS & 1.674 & 0.00 & $\begin{array}{c}\text { Signifi } \\
\text { Kan }\end{array}$ \\
\hline SP - ROA & 0.06 & 0.00 & $\begin{array}{c}\text { Signifi } \\
\text { Kan }\end{array}$ \\
\hline
\end{tabular}

Sumber: Hasil Estimasi Amos

\section{Pengaruh Variabel EPS terhadap ROA}

Hasil uji-t pengaruh variabel Earning per Share (EPS) terhadap variabel Return 
on Asset pada PT. Elnusa Tbk menunjukan terdapat pengaruh signifikan pada $\alpha=5 \%$. Hal ini terlihat pada nilai $\mathrm{P}$ sebesar 0.00 yang lebih kecil dari nilai $\alpha=0.05(5 \%)$.

Nilai koefisien estimasi Earning per Share (EPS) adalah 1.674, artinya Earning per Share (EPS) berdampak positif terhadap Return on Asset (ROA). Setiap kenaikan 1\% Earning per Share (EPS) dengan asumsi variabel tetap akan meningkatkan Return on Asset (ROA) sebesar $1,67 \%$.

Earning per Share merupakan rasio yang digunakan untuk mengukur seberapa besar tiap lembar saham yang dapat menghasilkan keuntungan bagi pemiliknya. Nilai EPS PT. Elnusa Tbk berguna bagi para investor untuk mengambil keputusan investasi. Inevstor tentu saja mengharapkan keuntungan besar dari pembelian saham. Semakin besar nilai EPS PT Elnusa Tbk semakin besar kemungkinan pendapatan (Return) yang dapat diperoleh investor dari setiap lembar sahamnya. Sebaliknya, return yang rendah menunjukan pendapatan di bawah perkiraan. Nilai koefisien EPS yang positif mendorong investor untuk membeli saham PT. Elnusa Tbk, dan hal ini akan mempengaruhi Return on Asset (ROA).

\section{Pengaruh Variabel ROA terhadap SP}

Hasil uji-t pengaruh variabel Return on Asset (ROA) terhadap variabel Harga Saham (SP) pada PT. Elnusa Tbk menunjukan terdapat pengaruh signifikan pada $\alpha=5 \%$. Hal ini terlihat pada nilai $\mathrm{P}$ sebesar 0.00 yang lebih kecil dari nilai $\alpha=$ 0.05 (5\%). Nilai koefisien estimasi Return on Asset (ROA) adalah 0.06, artinya Return on Asset (ROA) berdampak positif terhadap Harga Saham (SP). Setiap kenaikan 1\% Return on Asset (ROA) dengan asumsi variabel tetap akan meningkatkan Harga Saham (SP) sebesar 0,06\%.

ROA mengukur efektifitas secara keseluruhan dari manajemen dalam menghasilkan laba dengan ketersediaan aset yang dimiliki perusahaan. Semakin tinggi nilai ROA suatu perusahaan maka semakin baik bagi perusahaan tersebut.
Investor akan memberikan respon positif terhadap nilai ROA yang tinggi. Dari hasil estimasi diperoleh koefisien ROA PT. Elnusa Tbk yang positif. Hal tersebut karena ROA mengukur keuntungan bersih yang diperoleh dari penggunaan aktiva. Semakin tinggi rasio ini maka produktivitas aset dalam memperoleh keuntungan bersih semakin baik. Hal ini menjadikan PT. Elnusa Tbk semakin menarik bagi investor karena tingkat pengembalian yang akan diterima oleh investor akan semakin besar. Dapat disimpulkan bahwa ROA akan mempengaruhi harga saham, dimana kenaikan nilai ROA akan meningkatkan harga saham dari perusahaan tersebut.

Berdasarkan analisa jalur di atas, variabel EPS dapat mempengaruhi Harga Saham (SP) melalui ROA. Hal ini menujukan bahwa hipotesis penelitian dapat diterima.

\section{SIMPULAN}

Pada PT. Elnusa Tbk, Earning per Share (EPS) berpengaruh terhadap Harga Saham (SP) melalui Return on Asset (ROA). Hal tersebut menunjukan bahwa variabel ROA merupakan variabel intervening atas pengaruh variabel EPS terhadap harga saham (SP). EPS berdampak positif terhadap ROA, dan ROA juga berdampak positif terhadap Harga Saham. Semakin besar nilai EPS dan ROA semakin tinggi harga saham. Hasil ini sesuai dengan teori pasar modal dan rasio keuangan.

\section{DAFTAR PUSTAKA}

1. Abdullah, H., Soedjatmiko., Hartadi, U., Pengaruh EPS, DER, PER, ROA dan ROE Terhadap Harga Saham Perusahaan Tambang Yang Terdaftar di BEI untuk Periode 2011-2013, Jurnal Ekonomi dan Bisnis Vol. 9 No.1-20, 2016.

2. Baye, M. R., Prince, J. T., Ekonomi Manajerial dan Strategi Bisnis, Jakarta: Salemba Empat, 2016. 
3. Bursa Efek Indonesia, Laporan Keuangan Tahunan, Retrieved from http://www.idx.co.id

4. Deitiana, T., Pengaruh Rasio Keuangan dan Pertumbuhan Penjualan Terhadap Deviden dan Implikasinya pada Harga Saham, Jurnal Akuntansi Vol. XVI No. 02, 2012, pp 191-208.

5. Fahmi, I., Analisis Kinerja Keuangan, Bandung: Alfabeta, 2012.

6. Ghozali, I., Model Persamaan Struktural Konsep \& Analisis Dengan Program AMOS 21, Semarang, 2013.

7. Gitman, L. J., Zutter, C. Z., Principles of Managerial Finance, $13^{\text {th }}$ Edition ed., Pearson Education Limited, 2012.

8. Hanum, Z., Pengaruh Return on Asset, Return on Equity dan Earning per Share terhadap Harga saham pad Perusahaan Otomotif Yang terdaftar di Bursa Efek Indonesia Periode 20082011, Jurnal Manajemen \& Bisnis Vol. 08 No.2, 2015, pp 1-9. 